\title{
Long Term and Standard Incubations of WST-I Reagent Reflect the Same Inhibitory Trend of Cell Viability in Rat Airway Smooth Muscle Cells
}

\author{
Lei-Miao Yin, Yin Wei, Yu Wang, Yu-Dong Xu and Yong-Qing Yang ${ }^{\bowtie}$ \\ Laboratory of Molecular Biology, Shanghai Research Institute of Acupuncture and Meridian, Yue Yang Hospital, Shanghai University of \\ Traditional Chinese Medicine, Shanghai 200030, China. \\ $\triangle$ Corresponding author: Fax: +86-21-54592134; E-mail: yyq@shutcm.edu.cn.
}

(ㅇ Ivyspring International Publisher. This is an open-access article distributed under the terms of the Creative Commons License (http://creativecommons.org/ licenses/by-nc-nd/3.0/). Reproduction is permitted for personal, noncommercial use, provided that the article is in whole, unmodified, and properly cited.

Received: 2012.09.20; Accepted: 2012.12.02; Published: 2012.12.13

\begin{abstract}
The WST-I assay is an efficient test for cell viability measurement and the standard incubation time is $2 \mathrm{~h}$. In order to test if one-time addition of WST-I reagent can reflect the relative cell viability trend of the testing agents at different time points, the effects of $2 \mathrm{~h}$ standard incubation time and long term incubation time $(2 h+24 h, 2 h+48 h)$ of WST-I were compared in the rat airway smooth muscle cells (ASM cells) after adding of the testing protein MRP-I4. Our study demonstrated that the effect of different dosages of the protein after $2 \mathrm{~h}$ WST-I incubation on ASM cells showed a tendency of inhibition and achieved the maximal inhibition effect at $72 h$. The relative cell viability trend of the $2 h+24 h$ group was the same to that of the $2 \mathrm{~h}$ WST-I incubation, which means that $24 \mathrm{~h}$ prolonged incubation time of WST-I reagent could still reflect the relative cell viability trend. In conclusion, the study suggested that the WST-I is a proper candidate reagent for continuous monitation of cell viability.
\end{abstract}

Key words: WST-1, Cell viability, Rat airway smooth muscle cells.

\section{Introduction}

The cell viability measurement is one of the most fundamental tests in different forms of cell culture, which tests the number of healthy cells in a sample. There are more than 10 types of methods for investigating cellular viability[1], such as the trypan blue dye exclusion assay, the resazurin-based methods (alamar blue), the measurement of up-taking radioactive labeled ${ }^{3} \mathrm{H}$-thymidine into cellular DNA, and the reduction of different kinds of tetrazolium salts, etc[2]. The trypan blue dye exclusion assay is the earliest method for assessing cell viability, which is still used today due to the simplicity of both operations and reagents. The resazurin-based methods can be measured by both colourimetry and fluorimetry, which was reduced to a pink fluorescent dye in the medium by cell activity[3]. Measuring the up-taking of ${ }^{3} \mathrm{H}$-thymidine is another classic method, although it involves the application of radioactive products and special facilities. The cell viability status can also be simply reflected by the metabolic activity, which is capable of being estimated quantitatively by adding tetrazolium salts to cells[4].

The colorimetric methods have been wildly used nowadays, such as MTT (3-(4,5-Dimethylthiazol-2-yl)2,5-diphenyltetrazolium bromide), XTT (2,3-bis(2methoxy-4-nitro-5-sulphophenyl)-5-carboxanilide-

2H-tetrazolium, monosodium salt), MTS (3-(4,5-dimethylthiazol-2-yl)-5-(3-carboxymethoxyphe nyl)-2-(4-sulfophenyl)-2H-tetrazolium, inner salt), WST-1 (2-(4-iodophenyl)-3-(4-nitrophenyl)-5-(2,4disulfophenyl)-2H-tetrazolium, monosodium salt), etc. The MTT assay is one of the the most commonly used ways to detect the level of cell methabolism, which produces an intense color upon cellular reduc- 
tion due to the formation of water insoluble formazan[5]. However, the MTT method needs to break the cells and dissolve the precipitates. The assay takes approximately $44-52 \mathrm{~h}$ and should be measured at $570 \mathrm{~nm}[6,7]$. As the second generation tetrazolium dyes, the XTT could be transformed to a water-soluble formazan derivative which absorbs light at 430-490 $\mathrm{nm}$ in the presence of active mitochondria[8]. The absorbance range of another tetrazolium dye MTS was $515-580 \mathrm{~nm}$ and the color development speed is fast[9].

The WST-1 reagent could be reduced to highly water soluble formazan by cellular dehydrogenases in the presence of intermediate electron acceptor, such as mPMS (1-methoxy-5-methyl-phenazinium methyl sulfate)[10]. The mechanism is shown in the Figure 1. The formazan produced by WST-1 is more soluble than that of XTT and MTS, which leads to a wider linear range and higher sensitivity. Though it is reported that WST-1 derivant could still be metabolized to the formazan product after $48 \mathrm{~h}$ incubation[11], the standard incubation time of WST-1 time is $2 \mathrm{~h}[6]$. Whether one-time addition of WST-1 can reflect the effect of the testing agents at different time points on the trend of relative cell viability is still unclear.

In order to improve efficiency and simplify manipulation, the effects of $2 \mathrm{~h}$ standard incubation time and long term incubation $(2 h+24 h, 2 h+48 h)$ of WST- 1 in the rat airway smooth muscle cells were compared after adding of the testing protein MRP-14. We want to investigate if the long term incubation of WST-1 reagent can reflect the trend of relative cell viability at $24 \mathrm{~h}, 48 \mathrm{~h}$, and $72 \mathrm{~h}$, which could be used potentially in the continuous monitation of cell viability.

\section{Method}

\section{Chemicals and reagents}

All chemicals were analytical grade. WST-1 reagents (Beyotime), Dulbecco's modified eagle's medium (DMEM, Hyclone), fetal bovine serum (FBS, Gibco), phosphate buffered saline (PBS, Hyclone), $0.25 \%$ trypsin-EDTA solution (Gibco), penicillin-streptomycin solution $(10,000 \mathrm{U} / \mathrm{ml}$ penicillin and $10,000 \mu \mathrm{g} / \mathrm{ml}$ streptomycin, Hyclone), Spectrophotometer (Bio-tek). The $100 \mathrm{~cm}^{2}$ cell culture dishes and 96-well plates were purchased from Corning. The MRP-14 recombinant protein was purified by our previous study[12], which is a $13 \mathrm{kDa}$ soluble protein and has two $\mathrm{Ca}^{2+}$-binding EF-hand motifs[13].

\section{Isolation and culture of rat airway smooth muscle (ASM) cells}

Rat trachea was placed into the sterile, ice-cold,
HPPS solution $(\mathrm{NaCl} 130.0 \mathrm{mM}, \mathrm{KCl} 5.0 \mathrm{mM}$, $\mathrm{MgCl}_{2} \cdot 6 \mathrm{H}_{2} \mathrm{O} 1.2 \mathrm{mM}$, HEPES $10.0 \mathrm{mM}$, and glucose $10.0 \mathrm{mM}, \mathrm{pH}=7.4)$. The surrounding redundant tissue was dissected from cartilage and washed. The trachea was then cutted into pieces and digested for $30 \mathrm{~min}$ at $37^{\circ} \mathrm{C}$ in HPPS solution containing $2.0 \mathrm{mg} / \mathrm{ml}$ collagenase IV and $0.05 \%$ elastase. Enzyme digests were subsequently centrifuged at $1000 \mathrm{rpm}$ for $5 \mathrm{~min}$, and the pellet was resuspended and cultured in DMEM supplemented with $10 \% \mathrm{FBS}, 100 \mathrm{U} / \mathrm{ml}$ penicillin and $100 \mu \mathrm{g} / \mathrm{ml}$ streptomycin, at $37^{\circ} \mathrm{C}$ in a $5 \% \mathrm{CO}_{2}$ atmosphere. The culture medium was renewed every 2-3 days and experiments were performed with cells on passages 3-10. The ASM cells were confirmed by the light microscope and the immunofluorecent test confirmed that more than $95 \%$ of primary culture cells expressed contractile protein SM a-actin, which was the specific marker of airway smooth muscle.

\section{Incubation of WST-I}

ASM cells were harvested by trypsinization and were resuspended in DMEM containing $10 \%$ FBS. The cells were then plated at a density of 5000 cells per well into the 96-well plates and incubated overnight. The MRP-14 recombinant protein was given at the concentration of $1,10,50,100,200,400,800 \mathrm{ng} / \mathrm{ml}$ (final concentration) into totally three 96-well plates and incubated for $24 \mathrm{~h}, 48 \mathrm{~h}, 72 \mathrm{~h}$, respectively. Five replicates were used at each concentration and the PBS buffer was added in the control group. After adding the WST-1 into the first plate, the reagent was kept in the 96-well plate and incubated for $2 \mathrm{~h}$ (standard incubation time), $2 \mathrm{~h}+24 \mathrm{~h}$ and $2 \mathrm{~h}+48 \mathrm{~h}$ (long term incubation). The last two measurements were taken at the same time with the $2 \mathrm{~h}$ incubation of WST- 1 at $48 \mathrm{~h}$ and $72 \mathrm{~h}$. The detailed protocol was shown in the Figure 2. The absorbance at $450 \mathrm{~nm}$ was monitored and the reference wavelength was set at $630 \mathrm{~nm}$. The relative cell viability percentage in each group was calculated by comparison to that of the control group.

\section{Statistics}

All data are expressed as the mean \pm SD. Statistical significance between different groups in the WST-1 incubation study was calculated using One-way ANOVA followed by LSD posthoc test. P values lower than 0.05 were considered significant.

\section{Result}

According to the data of $2 \mathrm{~h}$ incubation of WST-1, the different dosages of MRP-14 recombinant protein showed a tendency of inhibition and achieved the maximal inhibition effect at $72 \mathrm{~h}$. At $24 \mathrm{~h}$, there was no significant difference between different groups 
$(\mathrm{F}=1.402, \mathrm{P}>0.05)$, though the dosages of 50,100 , and $800 \mathrm{ng} / \mathrm{ml}$ proteins had showed an inhibition tendency on ASM cells (Figure 3A). At 48h, there was a significant difference between different groups $(\mathrm{F}=9.859, \mathrm{P}<0.05)$ and the dosages of 400 and 800 $\mathrm{ng} / \mathrm{ml}$ proteins significantly inhibited the viability of ASM cells $(\mathrm{P}<0.05$ vs dosage of $1 \mathrm{ng} / \mathrm{ml}$, Figure $2 \mathrm{~B})$. The relative cell viability trend of the $2 h+24 h$ group was the same to that of the 2h WST-1 incubation (Figure 3C). There was a significant difference between different groups $(\mathrm{F}=15.766, \quad \mathrm{P}<0.05)$ after $2 \mathrm{~h}+24 \mathrm{~h}$ incubation and the effect of the dosages of 200,400 and $800 \mathrm{ng} / \mathrm{ml}$ protein were significantly different from that of the $1 \mathrm{ng} / \mathrm{ml}$ dosage $(\mathrm{P}<0.05)$.
At $72 \mathrm{~h}$, there was a significant difference between different groups $(\mathrm{F}=9.533, \mathrm{P}<0.05)$ and the dosages of $50,100,200,400$, and $800 \mathrm{ng} / \mathrm{ml}$ proteins significantly inhibited the viability of ASM cells $(\mathrm{P}<0.05$ vs dosage of $1 \mathrm{ng} / \mathrm{ml}$, Figure 3D). The 800 $\mathrm{ng} / \mathrm{ml}$ intervention achieved the maximum effect. Although the relative cell viability trend of the $2 h+48 h$ group is different from that of the $2 \mathrm{~h}$ WST-1 incubation (Figure $3 \mathrm{E}$ ), there was a significant difference between different groups $(\mathrm{F}=2.504, \mathrm{P}<0.05)$ after $2 \mathrm{~h}+48 \mathrm{~h}$ incubation and the effect of the dosage of 800 $\mathrm{ng} / \mathrm{ml}$ protein was significantly different from that of the $1 \mathrm{ng} / \mathrm{ml}$ dosage $(\mathrm{P}<0.05)$.<smiles>Nc1ccc(-n2nc(-c3ccc(S(=O)(=O)O)cc3S(=O)(=O)O[Na])n[n+]2-c2ccc(I)cc2)cc1</smiles>

WST-1

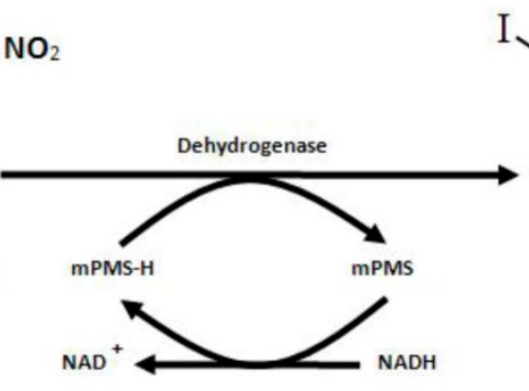

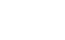<smiles>O=[N+]([O-])c1ccc(N/N=N/[C@H](/N=N/c2ccc(I)cc2)c2ccc(S(=O)(=O)[O-])cc2S(=O)(=O)[O-])cc1</smiles>

Formazan

Figure I Schematic mechanism of the WST-I reduction. With intermediate electron acceptor (such as mPMS), the WST-I reagent could be reduced to highly water soluble formazan by cellular dehydrogenases. Abbreviation: mPMS: I-methoxy-5-methyl-phenazinium methyl sulfate; NADH: Nicotinamide adenine dinucleotide.

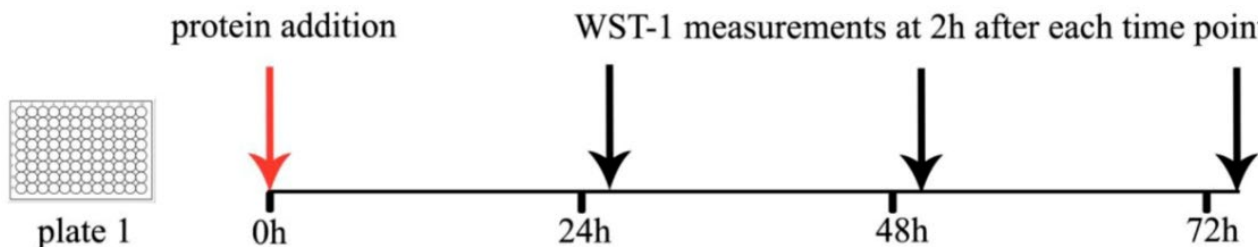

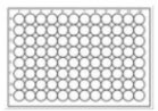

plate 2

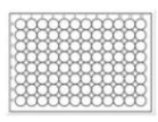

plate 3

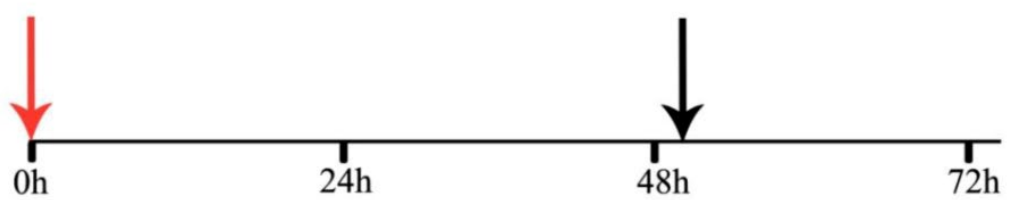

Figure 2 Schematic of the WST-I incubation study. The MRP-I 4 recombinant protein was added into totally three $96-$ well plates, which were measured at $24 \mathrm{~h}, 48 \mathrm{~h}, 72 \mathrm{~h}$, respectively. After adding the WST-I into the first plate, the reagent was kept in the 96 -well plate and incubated for $2 h, 2 h+24 h$ and $2 h+48 h$. The last two measurements were taken at the same time with the $2 h$ incubation of WST-I at $48 \mathrm{~h}$ and $72 \mathrm{~h}$. 

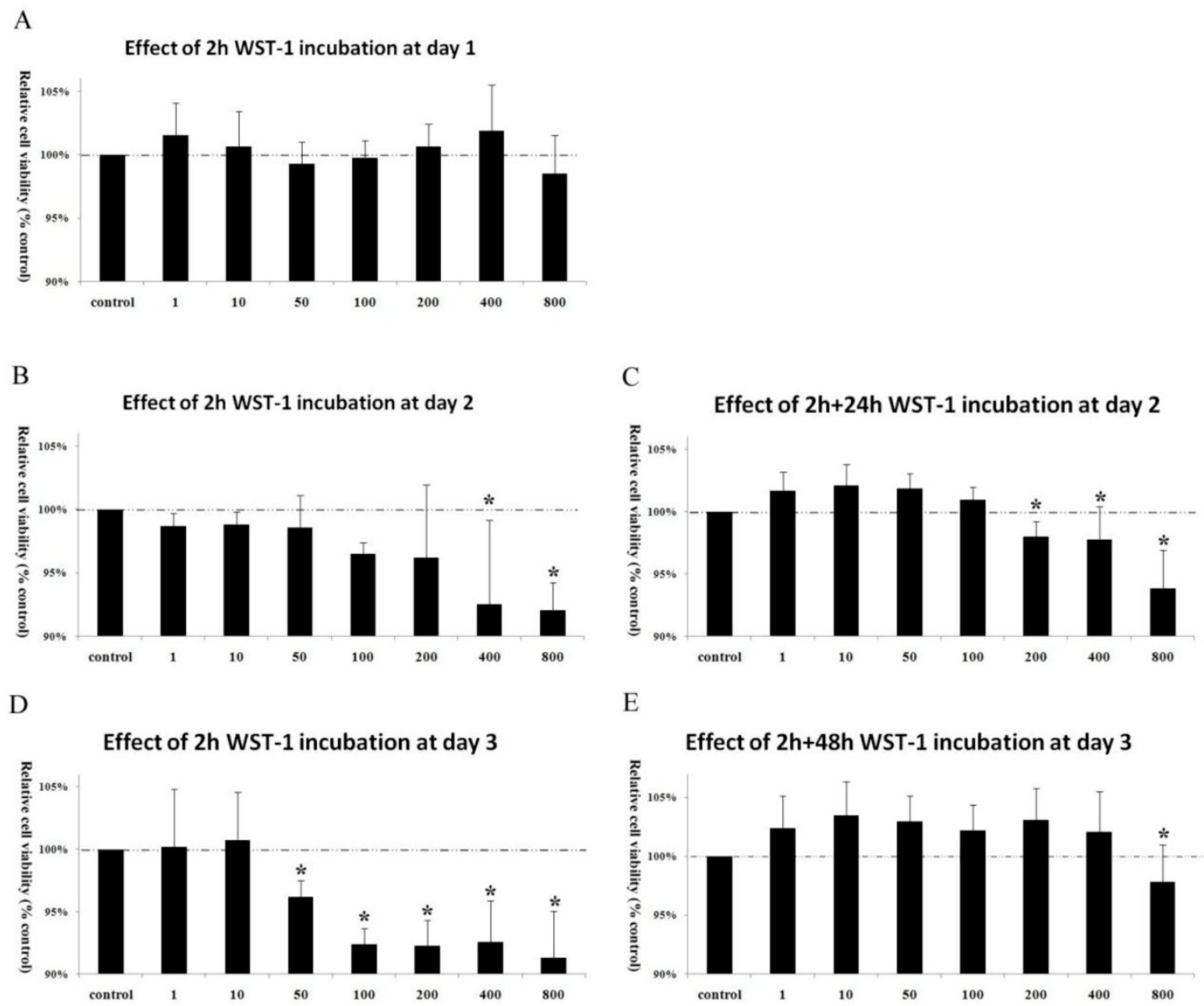

Figure 3 Effect of WST-I incubation at different time points. A) The effect of different dosages of protein after $2 \mathrm{~h}$ WST-I incubation on the rat airway smooth muscle (ASM) cells at 24h. B) The effect of different dosages of protein after $2 \mathrm{~h}$ WST-I incubation on ASM cells at $48 \mathrm{~h}$. The dosages of 400 and $800 \mathrm{ng} / \mathrm{ml}$ proteins significantly inhibited the viability of ASM cells $(\mathrm{P}<0.05 \mathrm{vs}$ dosage of I ng/ml). C) The effect of different dosages of protein after $2 \mathrm{~h}+24 \mathrm{~h}$ WST-I incubation on ASM cells at $48 \mathrm{~h}$. The dosages of $200,400 \mathrm{and} 800 \mathrm{ng} / \mathrm{ml}$ protein were significantly different from that of the $\mathrm{I} \mathrm{ng} / \mathrm{ml}$ dosage $(\mathrm{P}<0.05)$. D) The effect of different dosages of protein after $2 \mathrm{~h}$ WST-I incubation on ASM cells at $72 \mathrm{~h}$. The dosages of $50,100,200,400$, and $800 \mathrm{ng} / \mathrm{ml}$ proteins significantly inhibited the viability of ASM cells $(P<0.05$ vs dosage of $I \mathrm{ng} / \mathrm{ml})$. E) The effect of different dosages of protein after $2 \mathrm{~h}+48 \mathrm{~h}$ WST-I incubation on ASM cells at $72 \mathrm{~h}$. The dosage of $800 \mathrm{ng} / \mathrm{ml}$ protein was significantly different from that of the I $\mathrm{ng} / \mathrm{ml}(\mathrm{P}<0.05)$. All data are expressed as the mean $\pm S D, \mathrm{n}=5$.

\section{Discussion}

The inhibitory effect of MRP-14 on cell viability by using WST-1 is consistent with previous researches that showed the protein was related with the regulation of cellular processes, such as metabolism and cell cycle progression[14-15]. In the present study, we found that the $24 \mathrm{~h}$ prolonged incubation time of WST-1 reagent could still reflect the relative cell viability trend, which could be used potentially to continuous detection.

The investigation of cellular viability is a fundamental technique for the assessment of biological reaction of cell to outside stimuli. The WST-1 assay permits the measurement of a large number of samples without generating radioactive waste and exhibited higher precision, which now plays a important role in the investigation of cellular viability[16]. The assay steps of WST-1 are simple and the test time is short. It is reported that the WST-1 test was efficient and fast in screening for radiationsensitive cell lines in 120 cancer patients[17]. Besides, the WST-1 assay could also be used for $3 \mathrm{~h}$ rapid confirmation of toxigenic Bacillus species in foods[6]. However, WST-1 assay was usually performed once at a single time point. No previous study has traced the long term incubation at different time point after the addition of WST-1. Our study demonstrated that the relative cell viability trend of the $2 h+24 h$ group was the same to that of the $2 \mathrm{~h}$ WST-1 incubation, although the original OD values of the WST- 1 test at the $2 h+24 h$ was higher. The study suggested that the WST-1 reagent is proper for continuous monitation of cell viability. 


\section{Acknowledgements}

This work was supported by the National Natural Science Foundation of China (No. 81001548, 81173341, 81173332, 81202753), Shanghai Rising-Star Program (12QA1403000), "Chen Guang" project supported by Shanghai Municipal Education Commission and Shanghai Education Development Foundation (10CG45), and the Key Program of the State Administration of Traditional Chinese Medicine of China (S30304).

\section{Competing Interests}

The authors have declared that no competing interest exists.

\section{References}

1. Keshelava N, Frgala T, Krejsa J, Kalous O, Reynolds CP. DIMSCAN: a microcomputer fluorescence-based cytotoxicity assay for preclinical testing of combination chemotherapy. Methods Mol Med. 2005; 110: 139-53.

2. Stoddart MJ. Cell viability assays: introduction. Methods Mol Biol. 2011; 740: 1-6.

3. O'Brien J, Wilson I, Orton T, Pognan F. Investigation of the Alamar Blue (resazurin) fluorescent dye for the assessment of mammalian cell cytotoxicity. Eur J Biochem. 2000; 267: 5421-6.

4. Kupcsik L. Estimation of cell number based on metabolic activity: the MTT reduction assay. Methods Mol Biol. 2011; 740: 13-9.

5. Tominaga H, Ishiyama M, Ohseto F, Sasamoto K, Hamamoto T, Suzukic $\mathrm{K}$, et al. A water-soluble tetrazolium salt useful for colorimetric cell viability assay. Anal Commun. 1999; 36: 47-50.

6. Ngamwongsatit P, Banada PP, Panbangred W, Bhunia AK. WST-1-based cell cytotoxicity assay as a substitute for MTT-based assay for rapid detection of toxigenic Bacillus species using $\mathrm{CHO}$ cell line. J Microbiol Methods. 2008; 73: 211-5.

7. Pannecouque C, Daelemans D, De Clercq E. Tetrazolium-based colorimetric assay for the detection of HIV replication inhibitors: revisited 20 years later. Nat Protoc. 2008; 3: 427-34.

8. Moss BJ, Kim Y, Nandakumar MP, Marten MR. Quantifying metabolic activity of filamentous fungi using a colorimetric XTT assay. Biotechnol Prog. 2008; 24: 780-3.

9. Buttke TM, McCubrey JA, Owen TC. Use of an aqueous soluble tetrazolium/formazan assay to measure viability and proliferation of lymphokine-dependent cell lines. J Immunol Methods. 1993; 157: 233-40.

10. Berridge MV, Herst PM, Tan AS. Tetrazolium dyes as tools in cell biology: new insights into their cellular reduction. Biotechnol Annu Rev. 2005; 11: 127-52.

11. Ishiyama M, Shiga M, Sakamoto K, Mizoguchi M, He PG. A New Sulfonated Tetrazolium Salt That produces a Highly Water-soluble Formazan Dye. Chem Pharm Bull. 1993; 41: 1118-22.

12. Yin LM, Li HY, Zhang QH, Xu YD, Wang Y, Jiang YL, et al. Effects of S100A9 in a rat model of asthma and in isolated tracheal spirals. Biochem Biophys Res Commun. 2010; 398: 547-52.

13. Itou H, Yao M, Fujita I, Watanabe N, Suzuki M, Nishihira J, et al. The crystal structure of human MRP14 (S100A9), a $\mathrm{Ca}(2+)$-dependent regulator protein in inflammatory process. J Mol Biol. 2002; 316: 265-76.

14. Zhang C, Liu Y, Gilthorpe J, van der Maarel JR. MRP14 (S100A9) protein interacts with Alzheimer beta-amyloid peptide and induces its fibrillization. PLoS One. 2012; 7: e32953.

15. Ghavami S, Eshragi M, Ande SR, Chazin WJ, Klonisch T, Halayko AJ, et al. S100A8/A9 induces autophagy and apoptosis via ROS-mediated cross-talk between mitochondria and lysosomes that involves BNIP3. Cell Res. 2010; 20: 314-31.

16. Gieni RS, Li Y, HayGlass KT. Comparison of $[3 \mathrm{H}]$ thymidine incorporation with MTT- and MTS-based bioassays for human and murine IL-2 and IL-4 analysis. Tetrazolium assays provide markedly enhanced sensitivity. J Immunol Methods. 1995; 187: 85-93.

17. Guertler A, Kraemer A, Roessler U, Hornhardt S, Kulka U, Moertl S, et al. The WST survival assay: an easy and reliable method to screen radiation-sensitive individuals. Radiat Prot Dosim. 2011; 143: 487-90. 